\title{
Evaluation of the Genotoxicity of Acrylonitrile in Different Tissues of Male Mice
}

\author{
Maha A. Fahmy \\ Department of Genetics and Cytology, National Research Centre, Dokki, Cairo, Egypt \\ Accepted September 28, 1998
}

\begin{abstract}
Summary Acrylonitrile $(\mathrm{ACN})$ is an extensively produced industrial chemical used in the synthesis of plastics and fibers. It has been found in car exhaust, cigarette smoke, drinking water and food products. The ability of acrylonitrile to induce sister chromatid exchanges (SCE's) and chromosomal aberrations in male mice was investigated. Three dose levels of acrylonitrile $(5,7.5$, $10 \mathrm{mg} \mathrm{kg}^{-1}$ b.wt.) were tested (i.p.) for SCE's. The dose $10 \mathrm{mg} \mathrm{kg}^{-1}$ b.wt. induced significant increase in the frequency of SCE's $7.2 \pm 0.2$ /cell as compared with $4.4 \pm 0.26$ for control, but the rate of increase was significantly lower than that with mitomycin C $11.9 \pm 0.5$. Oral treatment with acrylonitrile induced a statistically significant increase in the percentage of chromosomal aberrations in mouse spermatocytes, bone-marrow as well as spleen cells. The aberration frequency increased with the dose and the number of treatments. In all experiments, mitomycin $\mathrm{C}$ induced much higher effect.

In conclusion acrylonitrile has shown clastogenic potential in the mice examined.
\end{abstract}

With the rapid industrial development, thousands of chemicals are being used. Many of them are toxic which can pollute the environment (air, land, water) and many human bodies through occupational exposure.

Acrylonitrile $(\mathrm{ACN})$ is an extensively produced industrial chemical used in the manufacture of acrylic fiber, nitrile rubber, resins and plastics. It is used as an intermediate in the synthesis of antioxidants, surface coatings, adhesives and dyes (Duverger-Van Bogaert et al. 1981). Moreover ACN had been used as a fumigant pesticide for stored grains and fruits (IARC 1979). In clinical practice acrylonitrile is used in the manufacture of high permeable dialysis tubing (Ward et al. 1993) and for synthesis of an artificial membrane to encapsulate Langerhans islets implants (Kessler et al. 1992). ACN is an environmental contaminant, which has been found in contaminated drinking water (Rubio et al. 1990) as well as food products infiltrated by ACN monomers from packing materials (Conacher et al. 1993). Cigarette smoke, car exhaust and industrial dust in work places have shown to contain many aliphatic nitriles including ACN (Baker et al. 1984, Byrd et al. 1990, Kondakova et al. 1990, Solionova et al. 1992). A significant increase in stomach and prostate cancer was observed in workers exposed to acrylonitrile (Werner and Carter 1981, Chen et al. 1988). Acrylonitrile was reported to be mutagenic in Salmonella typhimurium in the presence of liver S-9 fraction (Milvy and Wolff 1977) and in Chinese hamster ovary (Lambotte-Vandepaer and Duverger-Van Bogaert 1984). Recently ACN was reported to be positive in the yeast of Saccharomyces cerevisiae deletion (DEL) assay (Carls and Schiestl 1994).

In the present investigation, an attempt has been made to show the effect of acrylonitrile on mammalian chromosomes using the two cytogenetic parameters, sister chromatid exchange in bone-marrow and chromosomal aberration analysis in both somatic (bone-marrow and spleen) and germinal cells (spermatocytes) of male mice. 
Maha A. Fahmy

Cytologia 64

Materials and methods

Animals

Mature male Swiss mice (9-12 weeks old, weighing 25-30g) were used in all experiments. The animals were obtained from a closed random bred colony at the National Research Centre, maintained under controlled conditions of temperature and humidity and received feed and water ad libitum.

\section{Chemicals}

Acrylonitrile $\left(\mathrm{CH}_{2}=\mathrm{CH}-\mathrm{CN}\right.$, Vinyl Cyanide) $\mathrm{BDH}$ Chemicals Poole [England]; M. weight 53.06 Stabilized with $0.005 \%$ methoxyphenol. Impurity $99 \%$ minimum assay.

\section{Dosage and treatment}

Sister chromatid exchange The experimental procedure was conducted in accordance with the protocol of Allen (1982). The used doses were 5, 7.5 and $10 \mathrm{mg} \mathrm{kg}^{-1}$ b.wt. acrylonitrile. BrdU tablets, weighing approximately $55 \pm 2 \mathrm{mg}$, were placed subcutaneously. Mice were injected (i.p.) with acrylonitrile $8 \mathrm{hr}$ following BrdU treatment and with colchicine $2 \mathrm{hr}$ prior to killing. Metaphase spreads were prepared using the method of Yosida and Amano (1965). Differential staining of sister chromatids was performed according to the fluorescence plus Giemsa method of Goto et al. (1978) with the use of black lights. Only euploid cells $(2 \mathrm{n}=40)$ and well spread chromosomes were selected for scoring. 40 metaphase spreads per animal were examined microscopically for SCE's (200 metaphases per each treatment group). In all experiments, acrylonitrile was dissolved in distilled water.

Chromosomal aberration For spermatocytes, bone-marrow or spleen, single oral treatment via oral gavage was administered. Three different dose levels, $7.75,15.5$ and $31 \mathrm{mg} \mathrm{kg}^{-1}$ b.wt. (1/8, $1 / 4,1 / 2 \mathrm{LD}_{50}$ ) were used and mice killed $24 \mathrm{hr}$ after treatment. Oral $\mathrm{LD}_{50}$ was determined experimentally. The dose $7.75 \mathrm{mg} \mathrm{kg}^{-1}$ b.wt. acrylonitrile was given daily for 5 consecutive days and cell samples from spermatocytes, bone-marrow and spleen were taken $24 \mathrm{hr}$ after the third treatment and $24 \mathrm{hr}$ or 7 days after the fifth treatment. Untreated mice and mice injected with mitomycin $\mathrm{C}$ $1 \mathrm{mg} \mathrm{kg}^{-1}$ b.wt. were used as controls. Control and treated animals were injected with colchicine $2-3 \mathrm{hr}$ before killing. Primary spermatocytes at metaphase I (MI) were prepared from testes according to the air drying technique of Evans et al. (1964). Bone-marrow metaphases were prepared according to Yosida and Amano (1965). For spleen cells, fresh spleen was washed with RPMI medium and cut into small pieces. The cells were aspirated into a centrifuge tube and $0.075 \mathrm{M} \mathrm{KCl}$ was added. The cells were centrifuged at $1000 \mathrm{rpm}$ for $10 \mathrm{~min}$ and fixed in methanol-acetic acid $(3: 1)$ (Amer et al. 1993). Slides were stained with 7\% Giemsa in phosphate buffer. Around 75 metaphases were analysed per animal in five mice per group scoring the different types of chromosomal aberrations. Significant differences from controls were calculated with Student's t-test.

\section{Results and discussion}

The ability of acrylonitrile to induce sister chromatid exchanges (SCE's) in mouse bone-marrow cells was investigated (Table 1). SCE's are currently recognized as being a sensitive indicator of agents which damage mammalian DNA (Latt 1974) and their formation has been compared with that of mutation (Carrano et al. 1978, Wilkoskey and Rynard 1990). Three different dose levels of acrylonitrile $\left(5,7.5,10 \mathrm{mg} \mathrm{kg}^{-1}\right.$ b.wt.) were tested. The lowest dose tested had no significant effect with respect to SCE's while the higher doses increased the frequency of SCE's significantly. The mean frequency of SCE's reached 7.5 \pm 0.21 per cell after treatment with the highest dose which is less than twofold increase as compared with the negative control 4.4 \pm 0.26 . Comparing such fre- 
Table 1. Frequency of sister chromatid exchanges (SCE's) in mouse bone-marrow cells induced after i.p. treatment with different concentrations of acrylonitrile

\begin{tabular}{lcccc}
\hline \hline Treatment and doses & Mice No. & $\begin{array}{c}\text { Metaphases with } \\
\text { SCE's No. }\end{array}$ & SCE's No. & $\begin{array}{c}\text { SCE's/Cell } \\
\text { Mean } \pm \text { S.E. }\end{array}$ \\
\hline $\begin{array}{c}\text { I. Control } \\
\text { (non treated) }\end{array}$ & 5 & 200 & 880 & $4.4 \pm 0.26$ \\
II. Acrylonitrile & & & & \\
$\quad 5 \mathrm{mg} \mathrm{kg}^{-1}$ b.wt. & 5 & 200 & 1068 & $5.34 \pm 0.17$ \\
$7.5 \mathrm{mg} \mathrm{kg}^{-1}$ b.wt. & 5 & 200 & 1244 & $6.22 \pm 0.35^{*}$ \\
$10 \mathrm{mg} \mathrm{kg}^{-1}$ b.wt. & 5 & 200 & & $7.50 \pm 0.21^{* *}$ \\
Mitomycin C & & & 2381 & $11.9 \pm 0.5$ \\
$1 \mathrm{mg} \mathrm{kg}^{-1}$ b.wt. & 5 & 200 & & \\
$(+$ ve Control) & & & & \\
\hline
\end{tabular}

* Significant at 0.05 level. ** Significant at 0.01 level.

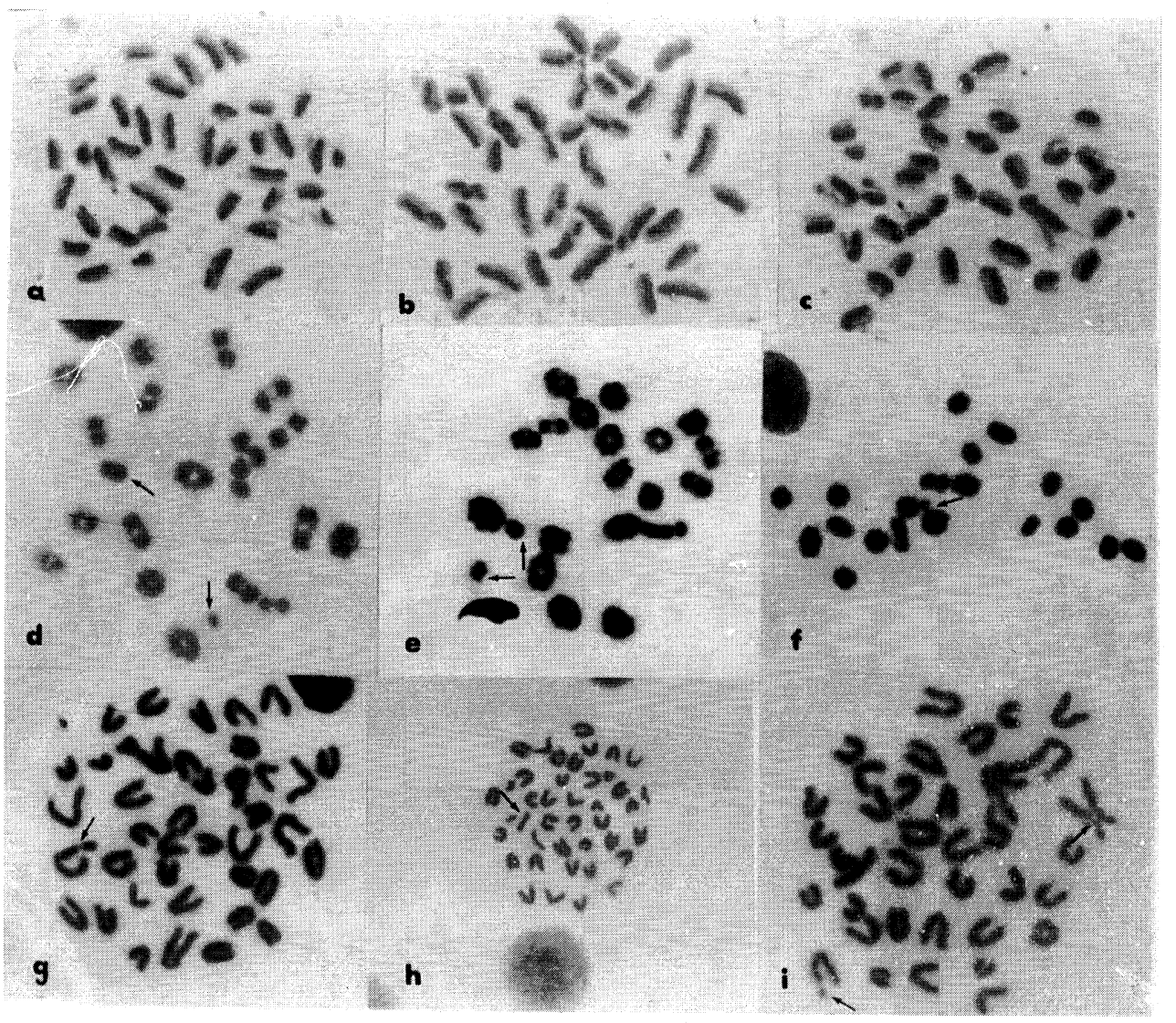

Fig. 1. Metaphases from mouse bone-marrow showing: SCE's induced by (a) Normal BrdU, (b) mitomycin C, (c) acrylonitrile. Metaphases from mouse spermatocytes showing. (d) $x-y$ univalent, (e) autosomal univalent, (f) fragment. Metaphases from mouse bone-marrow showing. (g) chromatid gap, (h) chromatid break, (i) A metaphase from spleen showing Robertsonian translocation (RT) and fragment. 


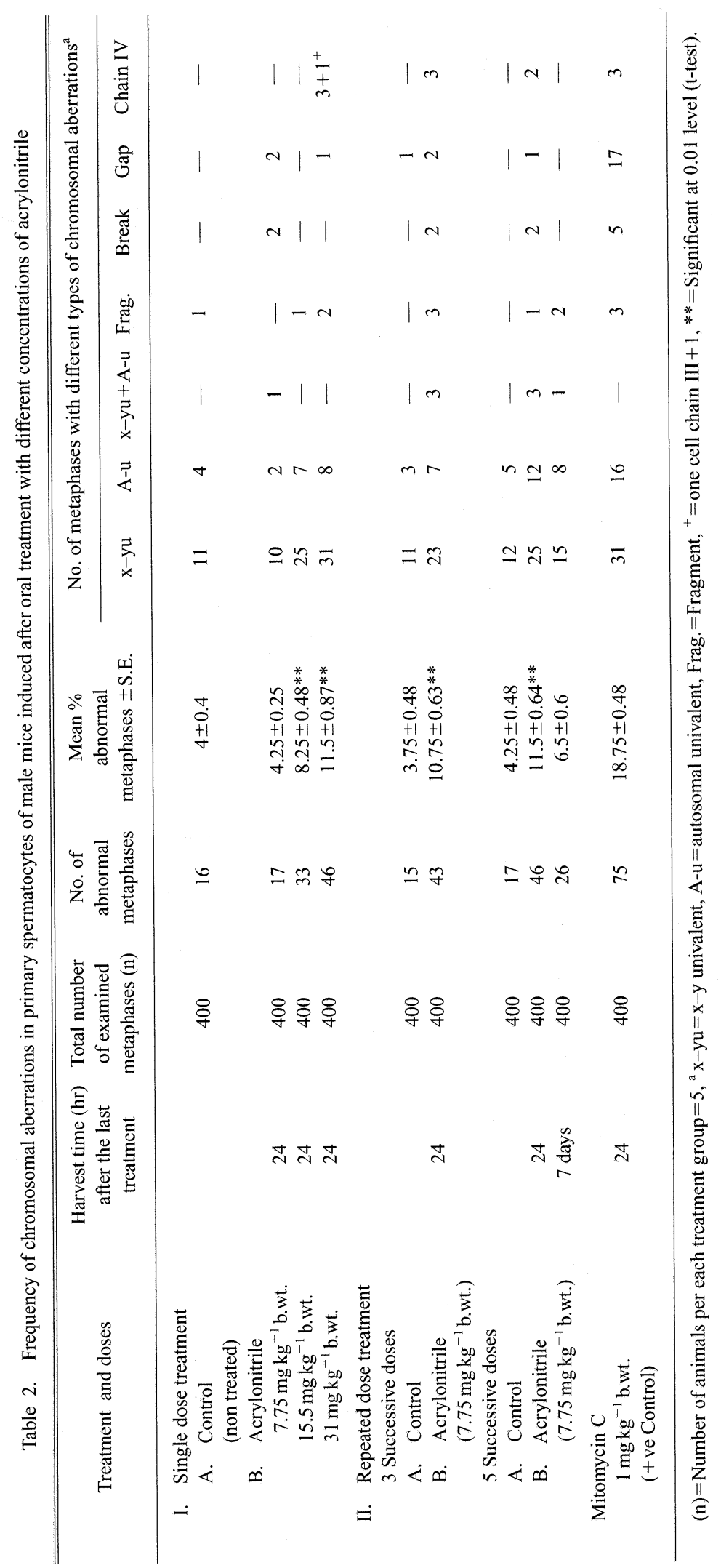




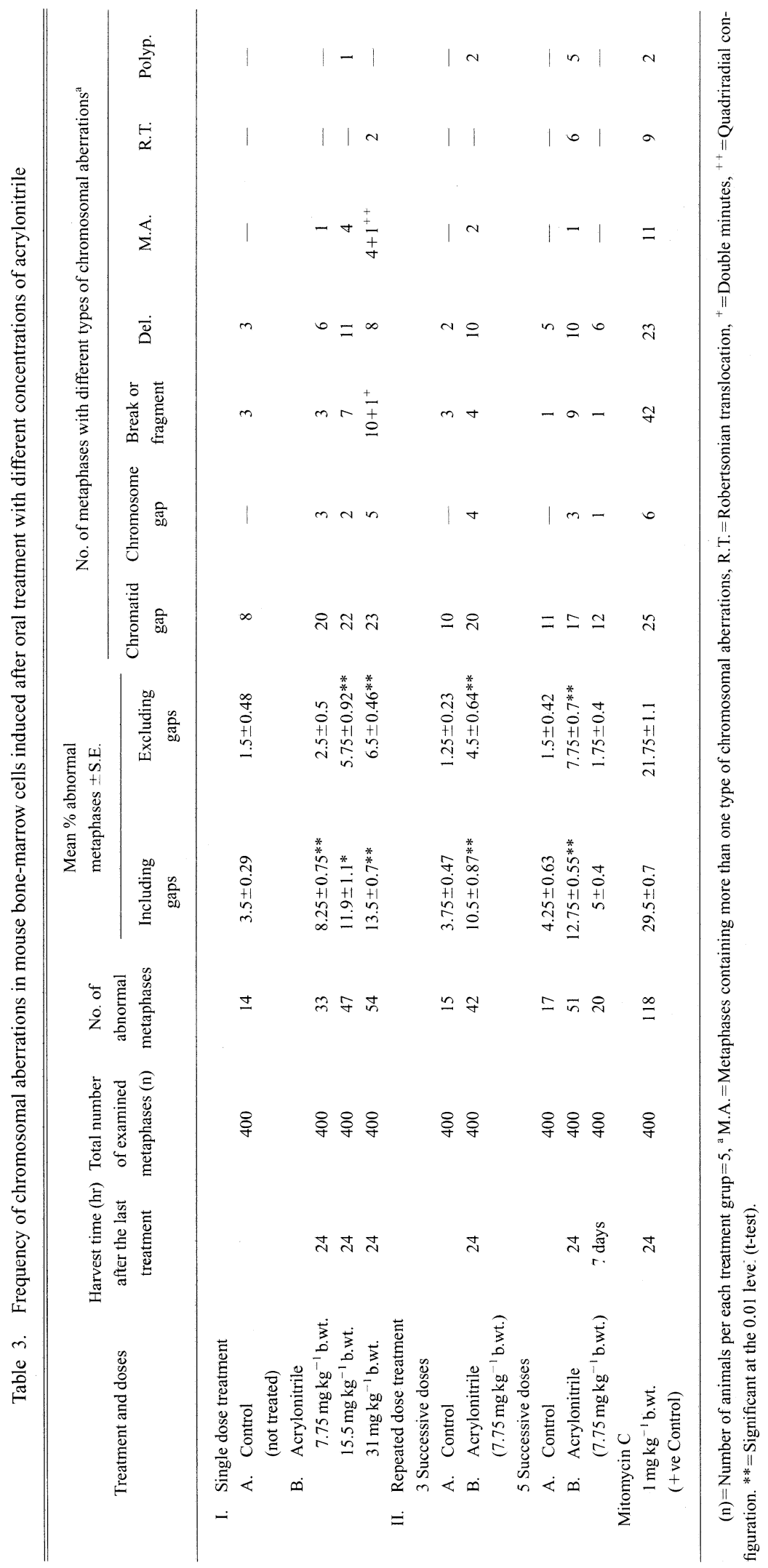




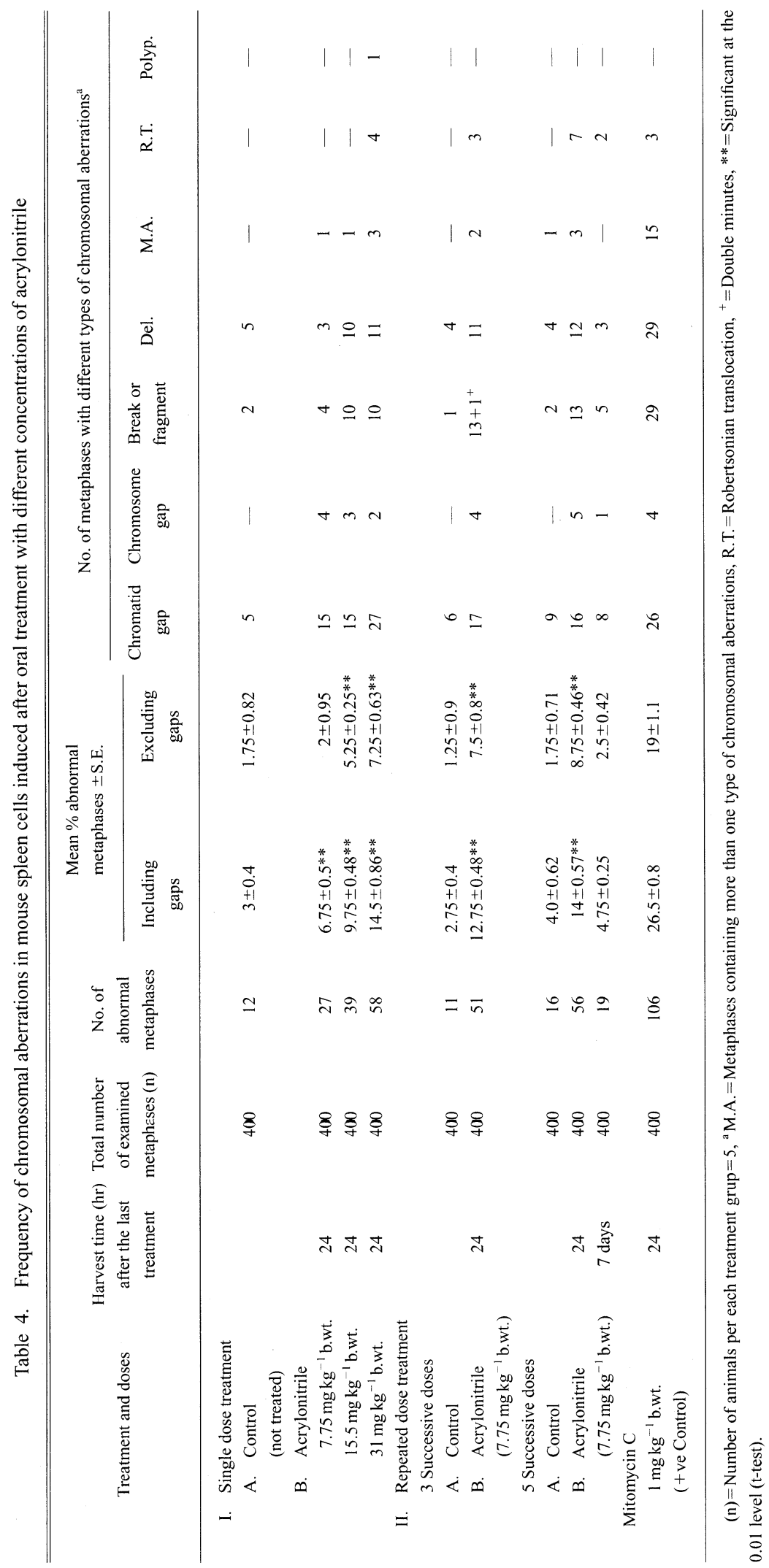


quency with that of mitomycin C $1 \mathrm{mg} \mathrm{kg}^{-1}$ b.wt. (+ve control), it was found that mitomycin C induced much higher effect $11.9 \pm 0.5$ (Fig. 1a-c). The results indicate that acrylonitrile is weak inducer of sister chromatid exchanges in mouse bone-marrow at the low doses.

Some authors recommended the study of chromosomal aberrations in germinal cells in which the transmissible genetic damage from one generation to another takes place (William and Hsu 1980, Hassan 1997). The results in single dose oral study showed that the tested doses of acrylonitrile with $1 / 8,1 / 4,1 / 2 \mathrm{LD}_{50}$ except the lowest one were capable of inducing significant increase in the percentage of chromosomal aberrations in mouse spermatocytes (Table 2). Such percentage reached $8.25 \pm 0.48$ and $11.5 \pm 0.87$ respectively after treatment with the doses 15.5 and $31 \mathrm{mg} \mathrm{kg}^{-1}$ b.wt. as compared with $4 \pm 0.4$ for the control non-treated. Such increase did not exceed the value of mitomycin $\mathrm{C}(18.75 \pm 0.48)$. Multiple treatment with the dose $7.75 \mathrm{mg} \mathrm{kg}^{-1} \mathrm{~b}$.wt. (1/8 $\mathrm{LD}_{50}$ ) caused higher percentage of chromosomal aberrations than single treatment. In mouse spermatocytes, no other aberrations other than structural aberrations were observed (Fig. 1d-f). Univalent formation was highly increased ( $\mathrm{x}-\mathrm{y}$ and autosomal univalents). However, $\mathrm{x}-\mathrm{y}$ univalents were much more frequent. Such a phenomenon was observed also by Imai et al. (1981). Ford (1969), reported that autosomal univalents may result from asynapsis (absence of zygotene pairing between homologous segments) or from desynapsis (separation due to the failure of chiasma formation). Precocious separation of $\mathrm{x}-\mathrm{y}$, or $\mathrm{x}-\mathrm{y}$ dissociation has been discussed as a mechanism of male sterility from radiation and mutagenic chemicals. Also breaks, fragments and gaps were observed. Translocation in the form of chain IV was observed in low percentage after the treatment with the highest dose and the treatment with multiple administration. This result is in agreement with the finding of Leonard (1976), Brewen and Preston (1978) who reported that chemicals (e.g. mitomycin $\mathrm{C}$, procarbazine and triethylenemelamine) induced low percentage of translocation which was recorded in high frequency after exposure to radiation (EL-Dawy 1993).

Acrylonitrile also induced significant increase in the percentage of chromosomal aberrations in bone-marrow as well as spleen cells even after excluding gaps $(\mathrm{p}<0.01)$ except with the lowest tested dose (single oral treatment) (Tables 3,4). The frequency of chromosomal aberrations increased as the concentration of acrylonitrile goes high. This fact indicates that the overall trend of response to the dose was significant.

Multiple treatment caused a higher percentage of chromosomal aberrations than single treatment. This may be due to the accumulation effect of acrylonitrile, since the animals in multiple treatment received 3 or 5 times more of the single treatment. Moreover chromosome aberrations returned to the normal level when mice were left to recover for 1 week after the last treatment which revealed complete elimination of acrylonitrile. Positive control data showed high frequency of chromosomal aberrations over those of the negative control and treated animals.

Concerning the different types of the aberrations observed (Fig. 1g-i), they were mainly of chromatid type (gaps, breaks, fragments, deletions). However metaphases carrying more than one type of structural chromosomal aberrations (multiple aberrations) were rare, while those with one aberration only were dominant. Robertsonian translocation (RT) appeared only with the highest tested dose of acrylonitrile and after repeated treatment. Numerical aberrations were rare and observed only in bone-marrow with repeated treatment. Accordingly the induction of chromosome aberrations following exposure to acrylonitrile revealed a potential for clastogenicity.

\section{Acknowledgment}

This work was supported by the project No. 3/3/2/12 of National Research Centre, Cairo, Egypt. The principal investigator of the project is Dr. Maha A. Fahmy. 


\section{References}

Allen, J. W. 1982. A Method for Conducing in vivo SCE Induction Analysis in Mice. Genetic Toxicology Division, U.S. Environmental Protection Agency, Research Triangle Park, North Carolina, 27711.

Amer, S. M., Ibrahim, A. A. E. and El-Sherbeny, K. M. 1993. Induction of chromosomal aberrations and sister chromatid exchange in vivo by the insecticide cypermethrin. J. App. Toxicol. 13: 341-345.

Baker, R. R., Dymond, H. F. and Sillabeer, P. K. 1984. Determination of $\alpha, \beta$ unsaturated compounds formed by burning cigarette. Anal. Proc. 21: 135-137.

Brewen, G. J. and Preston, R. J. 1978. Chromosome aberrations as a measure of mutagenesis. Comparison in vitro and in vivo in somatic and germ cells. Environ. Health Perspect. 6: 157-166.

Byrd, G. D., Fowler, K. W., Hicks, R. D., Lovette, M. E. and Borgerding, M. F. 1990. Isotope dilution gas chromatographymass spectrometry in the determination of benzene, toluene, styrene and acrylonitrile in mainstream cigarette smoke. J. Chromatogr. 503: 359-368.

Carls, N. and Schiestl, R. H. 1994. Evaluation of the yeast DEL assay with 10 compounds selected by the International Program of Chemical Safety for the evaluation of short-term tests for carcinogens. Mut. Res. 320: 293-303.

Carrano, A. V., Thompson, L. H., Lindl, P. A. and Minkler, J. L. 1978. Sister chromatid exchanges as an indicator of mutagenesis. Nature 271: $551-553$.

Chen, J. H., Fayerweather, W. E. and Pell, S. 1988. Cancer incidence of workers exposed to dimethylformamide and/or acrylonitrile. J. Occup. Med. 30: 813-818.

Conacher, H. B., Page, B. D. and Ryan, J. J. 1993. Industrial chemical contaminants of foods. Food Addit. Contam. 10: $129-143$.

Duverger-Van Bogaert, M., Lambotte-Vandepaer, M., De Meester, C., Rollmann, B., Poncelet, F. and Mercier, M. 1981. Effect of several factors on the liver extract mediated mutagenicity of acrylonitrile and identification of four new in vitro metabolites. Toxicol. Lett. 7: 311-319.

El-Dawy, H. 1993. Genetic studies on the effect of different types of irradiation on mice. Ph. D. Thesis, Department of Zoology, Ain-Shams University.

Evans, E. P., Breckon, G. and Ford, C. E. 1964. An air drying method for meiotic preparation from mammalian testes. Cytogenetics 3: 289-294.

Ford, C. E. 1969. Meiosis in mammals. In: K. Benirschke (ed.), Comparative Mammalian Cytogenetics, pp. 91-106, Springer-Verlag, Berlin, Heidelberg, New York.

Goto, K., Maeda, S., Kano, Y. and Sugiyama, T. 1978. Factors involved in differential Giemsa staining of sister chromatids. Chromosoma 66: 351-359.

Hassan, N. H. 1997. Miconazole genotoxicity in mice. J. Appl. Toxicol. 17: 313-319.

IARC monographs on the evaluation of carcinogenic risk of chemicals to humans. 1979. Some monomers, plastics and synthetic elastomers and acrolein. 19: 73-113.

Imai, H. T., Matsuda, Y., Shiroishi, T. and Moriwaki, K. 1981. High frequency of x-y chromosome dissociation in primary spermatocytes of $\mathrm{F}_{1}$ hybrids between Japanese wild mice (Mus musculus molossinum) and inbred laboratory mice. Cytogenet. Cell Genet. 29: 953-954.

Kessler, L., Pinget, M., Aprahamian, M., Poinsot, D., Keipes, M. and Damage, C. 1992. Diffusion properties of an artificial membrane used for Langerhans islets encapsulation: interest of an in vitro test. Transplant. Proc. 24: 953-954.

Kondakova, L. V., Fomina, E. I. and Alekseeva, O. V. 1990. Composition of volatile thermo-destruction components of automobile brake straps. Gig. Tr. Prof. Zabol. 3: 18-21.

Lambotte--Vandepaer, M. and Duverger-Van Bogaert, M. 1984. Genotoxic properties of acrylonitrile. Mut. Res. 134: 49-59.

Latt, S. A. 1974. Sister chromatid exchanges, indices of human chromosome damage and repair: detection by fluorescence and induction by mitomycin C. Proc. Natl. Acad. Sci. (USA) 71: 3162-3166.

Leonard, A. 1976. Heritable chromosome aberrations in mammals after exposure to chemicals. Radiat. Environ. Biophys. 13: $1-8$.

Milvy, P. and Wolff, M. 1977. Mutagenic studies with acrylonitrile. Mut. Res. 48: 271-278.

Rubio, R., Galceran, M. T. and Rauret, G. 1990. Nitriles and isonitriles as interferents in cyanide determination in polluted waters. Analyst 115: 959-963.

Solionova, L. G., Smulerich, V. B., Turbin, E. V., Krivosheyeva, L. V. and Plotnikov, J. V. 1992. Carcinogens in rubber production in the Soviet Union. Scad. J. Work Environ. Health 18: 120-123.

Ward, R. A., Schaefer, R. M., Falkenhagen, D., Jashua, M. S., Hiland, A. and Gurland, H. J. 1993. Biocompatibility of a new high-permeability modified cellulose membrane for haemodialysis. Nephrol. Dialysis Transplant. 8: 47-53.

Werner, J. B. and Carter, J. T. 1981. Mortality of United Kingdom acrylonitrile polymerization workers. Br. J. Ind. Med. 28: 247-253.

Wilkoskey, T. C. and Rynard, S. M. 1990. Sister chromatid exchange. In: Hulka, B., Wilkosky, T. C. and Griffith, J. D. (eds.), 
Biological Markers in Epidemiology, pp. 147-172, Oxford University Press, New York.

William, W. Au. and Hsu, T. C. 1980. The genotoxic effects of adriamycin in somatic and germinal cells of the mouse. Mut. Res. 79: 351-361.

Yosida, T. H. and Amano, K. 1965. Autosomal polymorphism in laboratory bred and wild Norway rats, Rattus norvegicus, found in Misima. Chromosoma 16: 658-667. 